\title{
On the gratum species group of the genus Cheiracanthium C.L. Koch, 1839 (Aranei: Cheiracanthidae), with a description of a new species
}

\section{O группе видов gratum рода Cheiracanthium C.L. Koch, 1839 (Aranei: Cheiracanthidae), с описанием нового вида}

\author{
Sergei L. Esyunin, Viktor E. Efimilk \\ С.А. Есюнин, B.E. Ефимик
}

Perm State University, Bukireva Street 15, Perm 614600, Russia. E-mail: Sergei.Esyunin@psu.ru

Пермский государственный университет, ул. Букирева 15, Пермь 614600 Россия.

KEY WORDS: Araneae, diagnosis, redescription, Transbaikalia, yellow sac spiders.

КЛЮЧЕВЫЕ СЛОВА: Araneae, диагноз, переописание, забайкалье, желтые пауки-мешкопряды.

ABSTRACT. A new gratum species group of the genus Cheiracanthium consisting of 10 species is proposed and diagnosed. Cheiracanthium gratum Kulczyński, 1897 is redescribed and illustrated based on newly collected materials. A new species - C. buri sp.n. - from Buryatia (Russia) is described from a single male.

How to cite this paper: Esyunin S.L., Efimik V.E. 2021. On the gratum species group of the genus Cheiracanthium C.L. Koch, 1839 (Aranei: Cheiracanthidae), with a description of a new species // Arthropoda Selecta. Vol.30. No.2. P.239-244. doi: 10.15298/arthsel.30.2.11

РЕЗЮМЕ. Для 10 видов рода Cheiracanthium выделена и диагностирована новая группа видов gratum. Cheiracanthium gratum Kulczyński, 1897 переописан и проиллюстрирован на основе вновь собранных материалов. Новый вид - C. buri sp.n. из Бурятии (Россия) описан по одному самцу.

\section{Introduction}

Compared to other genera in the family Cheiracanthiidae, the genus Cheiracanthium C.L. Koch, 1839 is large, accounting for $59 \%$ of the species diversity (213 out of 362 species described in the family) [WSC, 2021]. Many authors have pointed out that the genus is paraphyletic and in need of a revision [Benoit, 1977; Deelemen-Reinhold, 2001; Marusik, Kovblyuk, 2011; Wunderlich, 2012; Bayer, 2014; Morano, Bonal, 2016]. A progress in revealing the phylogenetic structure of the genus is complicated by the fact that "almost half of its species are known from a single sex or juveniles" [Zhang et al., 2018], 36 from the males, 60 from the females and two from juveniles.

The first attempt to understand the taxonomic structure of the genus was undertaken by Deeleman-Rein- hold [2001], who proposed two species groups in the revision of the Southeast Asian Cheiracanthium [Ibid., 2001]. Based on the latest re-evaluation [Esyunin, Zamani, 2020], seven species groups of Cheiracanthium are diagnosed. Yet, the congeners of the insulanum species group proposed by Deeleman-Reinhold [2001] were moved to the genus Eutittha Thorell, 1878 [Esyunin, Zamani, 2020].

In a small spider collection from the Republic of Buryatia (Transbaikalia, Russia), we have discovered a new Cheiracanthium species similar to a number of Palaearctic species, which, in our opinion, form a homogeneous species group.

The goals of the present paper are (1) to propose and diagnose the gratum species group of Cheiracanthium, (2) to describe a new species, C. buri sp.n., and (3) to re-describe C. gratum Kulczyński, 1897 based on the male recently collected from Kazakhstan.

\section{Material and Methods}

The morphology of copulatory organs of Cheiracanthium species, for which reliable illustrations (i.e., lateral and ventral views of the male palp, and ventral views of the epigyne, and dorsal views of the vulva) are available, have been analyzed to identify the species that belong to the gratum species group. The character states based on an analysis of the copulatory organs follow Esyunin, Zamani [2020].

Stacks of colour images were manually generated using an Olympus OMD EM-10 digital camera with a Panasonic Lumix H-H025 $25 \mathrm{~mm}$ f/1.7 lens mounted on a Zeiss microscope. Digital images were prepared using Photoshop CS6 image stacking software.

All studied materials are deposited in the Zoological Museum of the Moscow State University, Moscow, Russia (ZMMU; curator K.G. Mikhailov).

The terminology of the copulatory organs and palpal and leg chaetotaxy follow those by Lotz [2007] and Zhang et al. [2018]. Length of leg segments was measured on the dorsal 

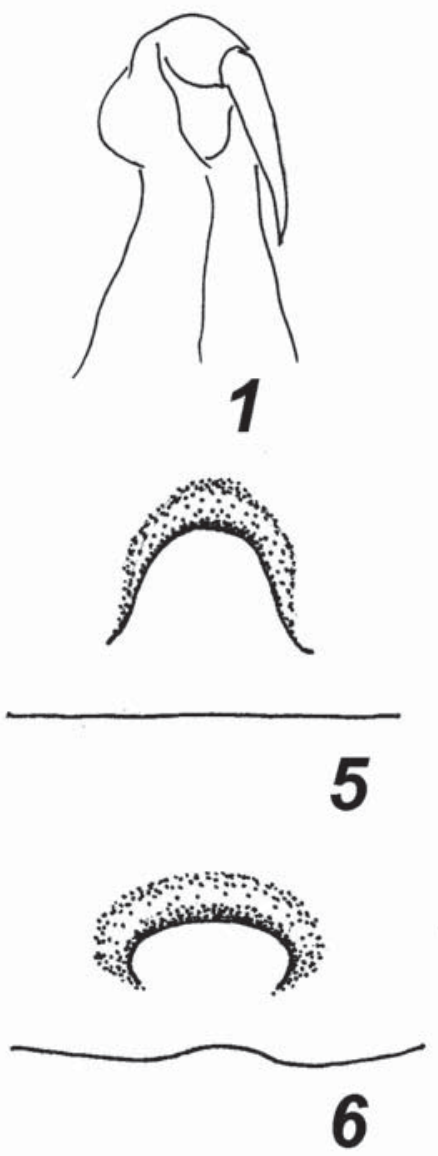
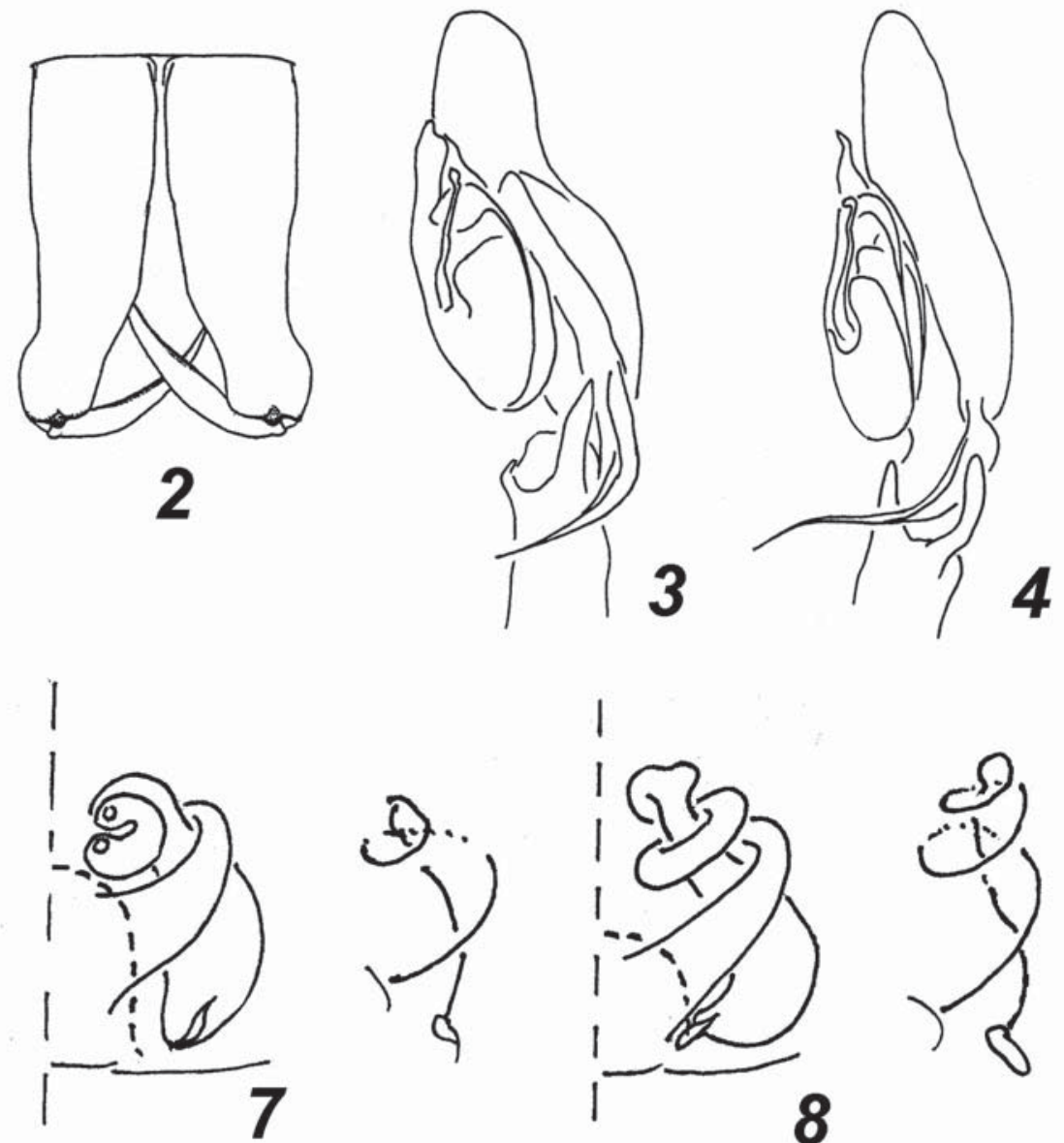
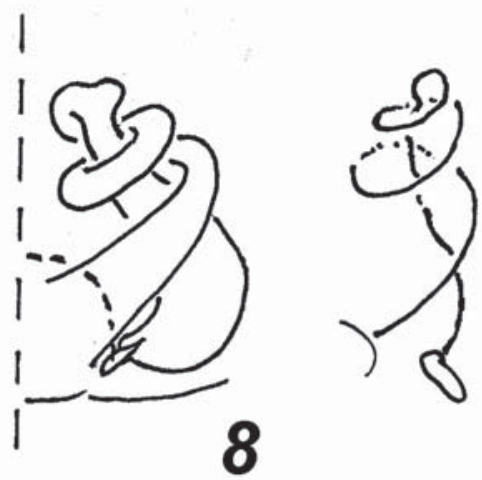

Figs 1-8. Some diagnostic characteristics of the gratum species group of Cheiracanthium: 1, 2 - chelicerae, mesal and frontal views, 3, 4 - palp, retrolateral view, 5, 6 - epigyne, ventral view, 7, 8 - endogyne with diagrammatic course of spermathecae, dorsal view. Figures are adopted from the following publications: 1 - Marusik \& Fomichev [2016: Fig. 4, C. vankhedei], 2, 5, 7 - Merkens, Wunderlich [2000: 3, 7, 8, C. gratum], 3 - Chen et al. [2006: 2D, C. falcatum], 4, 6, 8 - Paik [1990: 3, 6, 6, C. japonicum]).

Рис. 1-8. Некоторые диагностические характеристики Cheiracanthium из группы видов gratum: 1,2 - хелицеры, вид изнутри и спереди, 3, 4 - пальпы, вид сбоку, 5, 6 - эпигины, вид снизу, 7, 8 - эндогины со схемами сперматек, вид сверху. Иллюстрации заимствованы из следующих публикаций: 1 - Marusik, Fomichev [2016: Fig. 4, C. vankhedei], 2, 5, 7 - Merkens, Wunderlich [2000: 3, 7, 8, C. gratum], 3 - Chen et al. [2006: 2D, C. falcatum], 4, 6, 8 - Paik [1990: 3, 6, 6, C. japonicum]).

side and is presented as follows: total length (femur, patella+tibia, metatarsus, tarsus). All measurements are given in millimeters.

Abbreviations used in the text and figure plates are as follow: AER - anterior eye row, ALE - anterior lateral eye, AME - anterior median eye, DTA - dorsal tibial apophysis, MOQ - median ocular quadrangle, PER posterior eye row, PLE — posterior lateral eye, PME posterior median eye, PTA - prolateral tibial apophysis, RTA - retrolateral tibial apophysis, TA — tegular apophysis. Leg spination: $\mathrm{d}$ - dorsal, $\mathrm{v}$ - ventral, $\mathrm{pl}$ - prolateral, $\mathrm{rl}$ - retrolateral.

\section{Taxonomy}

Family Cheiracanthiidae Wagner, 1887 Genus Cheiracanthium C.L. Koch, 1839

The gratum species group of Cheiracanthium is quite homogeneous and can be diagnosed by the fol- lowing combination of genitalic characters: (1) cymbial fold well-visible, more or less triangular in ventral view; (2) embolic base in apical position (Figs 9, 11); (3) non-sclerotized, long, slender and hamiform TA (Figs 9, 11); (4) cymbial spur long, strongly curved ventrally and distinctly tapering at its distal section (Figs 3, 4); (5) long embolus forms a complete circle; (6) palpal tibia with large RTA and small PTA; DTA present (C. gratus, C. falcatum, $C$. ningmingense, $C$. simaoense) or absent (C. brevispinum, C. buri, C. ienisteai, C. japonicum, C. vankhedei, C. zebrinum); (7) epigyne with an atrium spaced from the epigastric fissure by a semilunar anterior margin (Figs 5, 6); (8) copulatory openings spaced and lateral; (9) kidney- or pear-shaped, compact spermatheca; (10) copulatory ducts twisted around the spermathecae one or two times (Figs 7, 8). For some species, a cheliceral modification has been described: viz., chelicerae curved outwards at 


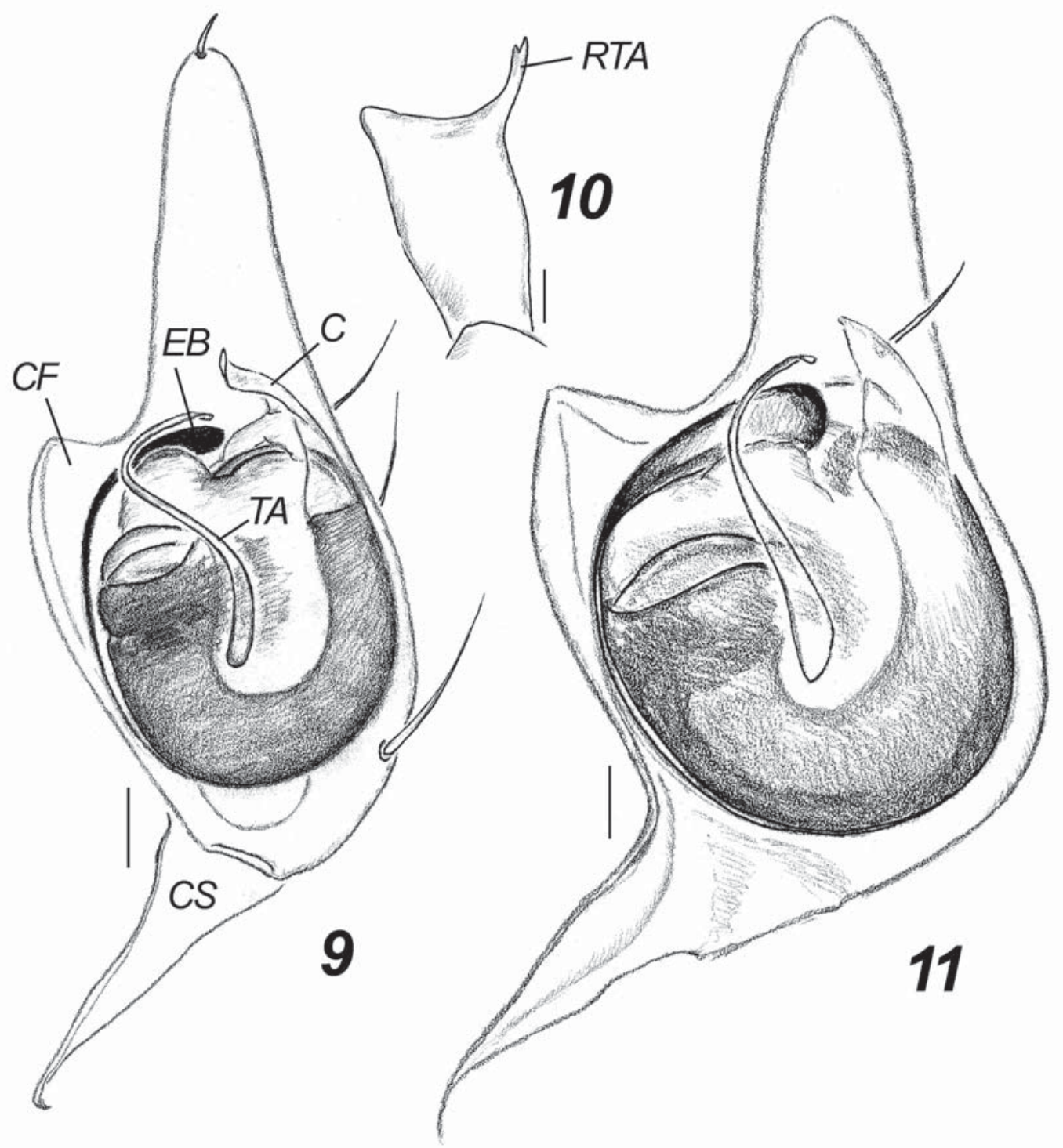

Figs 9-11. Male palps of Cheiracanthium gratum Kulczyński, 1897 (9) and C. buri sp.n. (10, 11): 9, 11 - palp, ventral view, 10 palpal tibia, ventral view. Scale bars: $9,11=0.1 \mathrm{~mm} ; 10=0.2 \mathrm{~mm}$. Abbreviations: $C$ - conductor; $C S-$ cymbial spur; $C F-$ cymbial fold; $E B$ - embolic base; $R T A$ - retrolateral tibial apophysis; $T A$ - tegular apophysis.

Рис. 9-11. Пальпы самцов Cheiracanthium gratum Kulczyński, 1897 (9) и C. buri sp.n. (10, 11): 9, 11 — пальпа, вид снизу, 10 голень пальпы, вид снизу. Масштаб: $9,11=0,1$ мм; $10=0,2$ мм. Сокращения: $C$ - кондуктор; $C S-$ шпора цимбиума; $C F-$ складка цимбиума; $E B$ - база эмболюса; $R T A$ - ретролатеральный отросток; $T A$ - тегулярный отросток.

their tip in C. gratus (Fig. 2), C. brevispinum and $C$. zebrinum, or with an apical bulge in $C$. vankhedei (Fig. 1). All the known species of gratum species group lack a dorsal red longitudinal median band on abdomen.

The characters $2,3,4,5,8,9$ and partly 6 and 10 are shared with representatives of the Palaearctic punctorium species group. The characters 1,7 and partly 6 and 10 distinguish the species of the gratum group from those of the punctorium group.

The following species can be assigned to the gratum species group with confidence; their distribution follows WSC [2021], full reference lists are also given in WSC [2021]:
C. gratum Kulczyński, 1897 (Europe, see also below),

C. brevispinum Song, Feng et Shang, 1982 (Mongolia, China, Korea),

C. buri sp.n. (Transbaikalia, see below),

C. falcatum Chen, Huang, Chen et Wang, 2006 (Taiwan),

C. ienisteai Sterghiu, 1985 (Romania, Albania),

C. japonicum Bösenberg et Strand, 1906 (The Russian Far East, Mongolia, China, Korea, Japan),

C. ningmingense Zhang et Yin, 1999 (China),

C. simaoense Zhang et Yin, 1999 (China),

C. vankhedei Marusik et Fomichev, 2016 (Mongolia), 

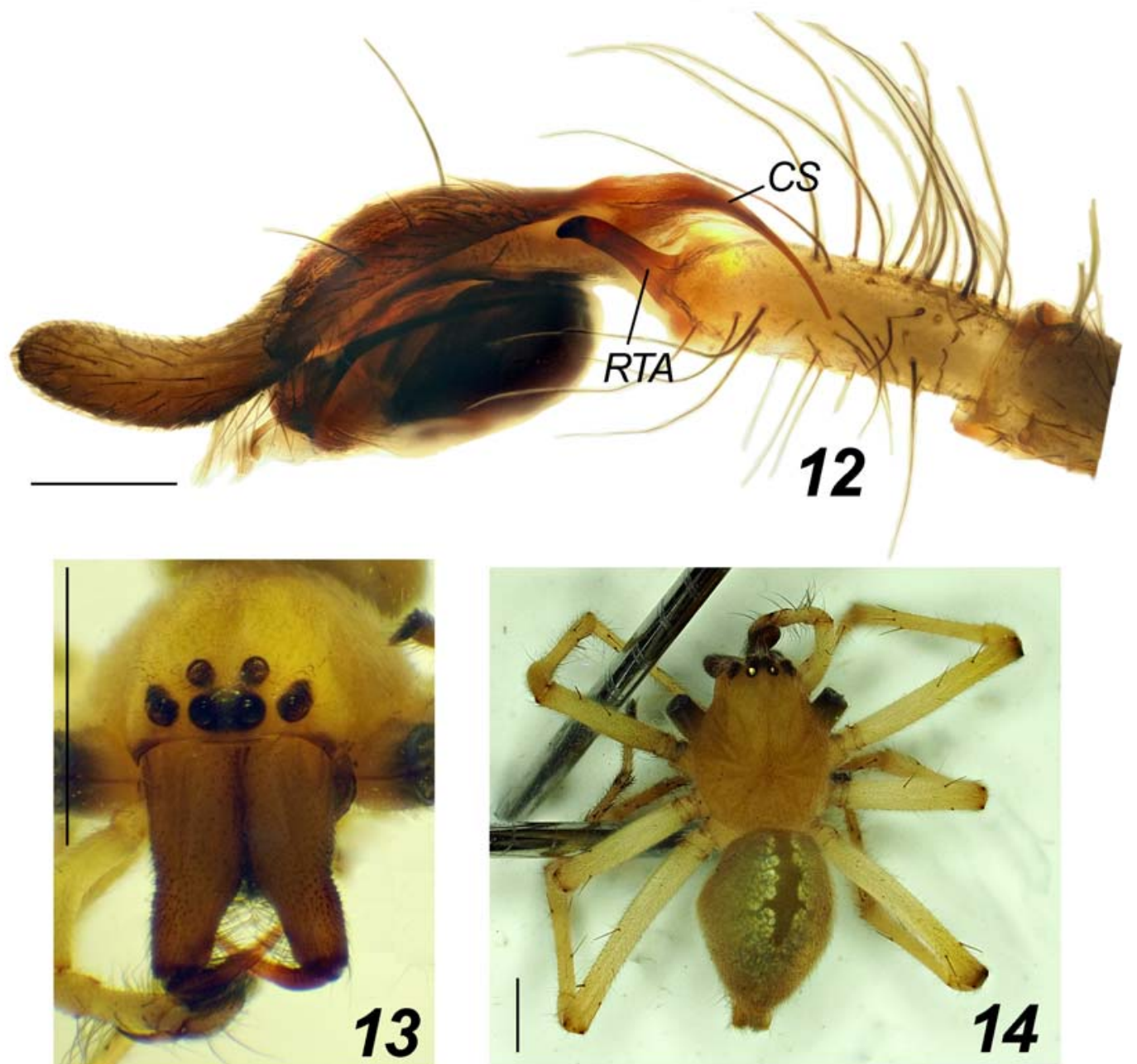

Figs 12-14. Cheiracanthium buri sp.n.: 12 - palp, retrolateral view, 13 - prosoma, frontal view, 14 - dorsal habitus. Scale bars: 12 $=0.2 \mathrm{~mm}, 13,14=1.0 \mathrm{~mm}$. Abbreviations: $C S$ - cymbial spur; $R T A-$ retrolateral tibial apophysis.

Рис. 12-14. Cheiracanthium buri sp.n.: 12 - пальпа, вид сбоку, 13 - головогрудь, вид спереди, 14 - общий вид сверху. Масштаб: $12=0,2$ мм, $13,14=1,0$ мм. Сокращения: $C S$ - шпора цимбиума; $R T A$ - ретролатеральный отросток голени.

C. zebrinum Savelyeva, 1972 (South Siberia, NE Kazakhstan).

\section{Cheiracanthium buri sp.n.} Figs 10-14.

TYPE. Holotype $\odot^{7}$ (ZMMU), Russia, Buryatia, Ivolginsky District, Mukhiskie Bogs, $51^{\circ} 47^{\prime \prime} \mathrm{N} 107^{\circ} 23^{\prime \prime} \mathrm{E}$, cryosolic meadow, pitfall traps, 31.V.2019, L. Khobrakova, S. Rudykh.

ETYMOLOGY. The species name is a noun in apposition originating from the Turkic word "бури" (buri) — the wolf-father, whom ancient Buryat clans revered as the progenitor; this word also served as the source of the ethnonym 'Buryat'.

DIAGNOSIS. The new species is most similar to $C$. gratum and $C$. vankhedei. The males of these three species have a long, strongly bent tip of the cymbium. C. buri differs from C. vankhedei in the absence of a bulge on the posterior side of chelicerae (cf. Fig. 1 and 13), the smaller body size (5.0 $\mathrm{mm}$, compared to 8.5 in C. vankhedei), and a less number of promarginal teeth $(2+3 v s .3+3)$ and spines on tibia II (a pair of prolateral spines vs. 2 pro- and 2 retrolateral spines).

C. buri sp.n. can be separated from C. gratum by the absence of cheliceral bulge (cf. Figs 13 and 17) and rounded tegulum (oval tegulum in C. gratum; cf. Figs 9 and 11), as well as by the presence of more cheliceral teeth ( 5 in total $v s$. 3 in $C$. gratum), less number of dorsal setae on the cymbium (2 vs. 4 in C. gratum) and less spines on tibia II (a pair of spines vs. two pair spines in C. gratum).

DESCRIPTION. Male. Habitus as in Fig. 14. Total length 5.0. Carapace 2.5 long, 1.9 wide; yellow. Sternum yellow. Legs yellow, with dark tarsus. Chelicerae weakly curved, with numerous short black setae anteriorly and laterally in their apical halves (Fig. 13), 0.8 long, brownish yellow; with 2 promarginal teeth and 3 retromarginal teeth. Endites and labium brownish yellow, with white apexes.

Clypeus height ( 0.08 from AME) half AME diameter. Ocular field black between AMEs (Fig. 13), AER straight, its width 0.90 , PER procurved, its width 1.01. MOQ trapezoid: 0.34 long, 0.39 wide anteriorly and 0.43 posteriorly. Eye sizes vary slightly: largest AME 0.15 , smallest ALE=PLE 


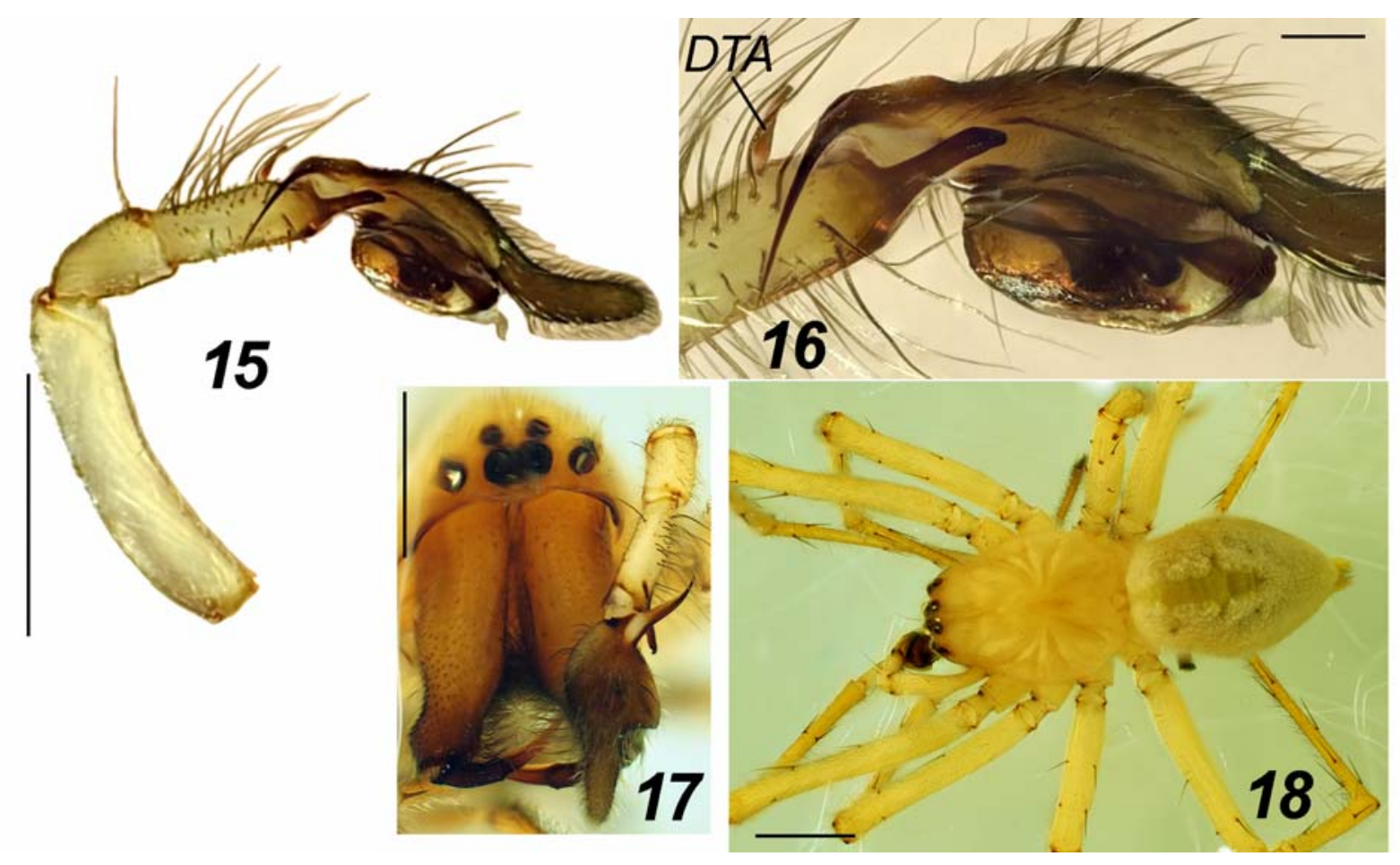

Figs 15-18. Cheiracanthium gratum Kulczyński, 1897: 15, 16 - palp, retrolateral view, 17 - prosoma, frontal view, 18 - dorsal habitus. Scale bars: $15,17,18=1.0 \mathrm{~mm}, 16=0.2 \mathrm{~mm}$. Abbreviations: $D T A-$ dorsal tibial apophysis.

Рис. 15-18. Cheiracanthium gratum Kulczyński, 1897: 15, 16 - пальпа, вид сбоку, 17 - головогрудь, вид спереди, 18 - общий вид сверху. Масштаб: 15, 17, 18 = 1,0 мм, 16 = 0,2 мм. Сокращение: $D T A-$ дорсальный отросток голени.

0.13. Eye interdistances: ALE-PLE touching; AME-ALE separated by less than a diameter, AME-AME, PME-PME separated by about a diameter, and PME-PLE separated by more than a diameter. AME-ALE 0.11, AME-AME 0.14, PME-PME 0.15, PME-PLE 0.21.

Leg formula: (I - absent)-IV-II-III. Leg measurements: II $9.3(2.6,3.3,2.5,0.9)$, III $7.0(2.0,2.2,2.1,0.7)$, IV 10.3 (3.0, 3.4, 3.0, 0.9). Leg spination: Femur II pl 0-1-1, III-IV pl 0-1(0)-1, rl 0-0-1; Tibiae II pl 0-0-1, v 0-0-2; III pl 0-0-1, rl 0-0-1; IV pl 0-0-1, rl 0-0-1, v 0-0(1)-0; Metatarsi II pl 0-10, v 2-1-1; III, IV pl 0-1-1, rl 0-1-1, v 2-2-3. Tarsi III-IV and apical part of metatarsi III with sparse scopulae; metatarsi IV with numerous long setae ventrally.

Abdomen elongate-oval, 2.5 long; yellowish white, with light lanceolate bands (Fig. 14).

Palp. Yellow, with dark brown cymbium. Measurements: femur 1.19 , patella 0.36 , tibia 0.56 , cymbium 1.02 . Palp spination: femur d1-1-1, patella d0-1-2, pl0-1-0, tibia with numerous long setae (Fig. 12), cymbium with 2 long dorsal setae, 1 retrolateral setae (on cymbial fold) and group (4-5) long setae on prolateral edge. Tibia short, about half of cymbium length (Fig. 12), with short RTA (about 0.4 times shorter than tibia); RTA bifurcated at its apex (Fig. 10). Rounded cymbium with long curved tip (about 0.3 times of length of cymbium). Cymbial spur (CS, Fig. 11, 12) curved, slightly shorter than tibia. Tegulum rounded; embolic base in apical position (Fig. 11); conductor membranous; TA long, thin and hook-shaped (Fig. 11).

Female. Unknown.

DISTRIBUTION. Known only from the type locality.
Cheiracanthium gratum Kulczyński, 1897 Figs 2, 5, 7, 9, 15-18.

C. gratum Kulczyński in Chyzer, Kulczyński, 1897: 236, Pl. 9, Figs $53,73\left(0^{7}\right)$.

C. gratum: Merkens, Wunderlich, 2000: 42, Figs 1-9 (O'T).

MATERIAL. KAZAKHSTAN: $1 \sigma^{7}$ (ZMMU), West Kazakhstan

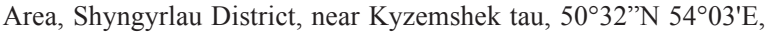
104 m a.1.s., 1.VII.2020, A. Kabdrakhimov.

DIAGNOSIS. For the male, see above under Diagnosis for C. buri; for the female, see Merkens \& Wunderlich [2000: 43].

DESCRIPTION. Male (Kazakhstan). Habitus as in Fig. 18. Total length 6.3. Carapace 2.8 long, 2.3 wide; yellow. Sternum yellow. Legs yellow with dark tarsus. Chelicerae weakly curved with numerous short black setae anteriorly and laterally in their apical halves (Fig. 17), 1.5 long, brownish yellow; with 3 promarginal teeth and 1 (0 left) retromarginal teeth. Endites brownish yellow, labium brown, with white apex.

Clypeus height (0.07 from AME) is half AME diameter. Ocular field black between AMEs (Fig. 17), AER straight, its width 0.98 , PER procurved, its width 1.09 . MOQ weakly trapezoid: 0.42 long, 0.42 wide anteriorly and 0.48 posteriorly. Eye sizes vary slightly: largest AME 0.17 , smallest PME 0.14. Eye interdistances: ALE-PLE touching; AME-ALE, AME-AME and AME-PME separated by about a diameter, PME-PME separated by 1.5 diameters, and PME-PLE separated by about two diameters. AME-ALE 0.15, AME-AME $=$ AME-PME 0.14, PME-PME 0.21, PME-PLE 0.27.

Leg formula: I-IV-II-III. Leg measurements: I 15.3 (4.0, 5.1, 4.2, 2.0), II 11.4 (3.2, 3.8, 3.2, 1.2), III 8.5 (2.4, 2.7, 2.5, 
$0.9)$, IV $12.1(3.5,3.9,3.6,1.1)$. Leg spination: Femur I pl 01(2)-1, rl 0-0-1, II pl 0-1-1, rl 0-1(0)-1, III pl 0-1-1, rl 0-1-1, IV pl 0-1-1, rl 0-0-1; Tibiae I v 2-2-0; II pl 0-0-1, v 2-2-0; III pl 0-0(1)-1, rl 0-0-1, v 0-2-0; IV pl 0-0-1, rl 0-0-1, v 2-0-0 (and long hairs); Metatarsi I, II pl 0-1-0, v 2-1-1; III pl 1-1(2)1, rl 0-1(0)-1, v 2-2(0)-3, IV pl 1-1-1, rl 1-1-1, v 2-2-3. Tarsi II-IV and apical part of metatarsi III apically with scopulae; tarsi I and metatarsi I, II and IV apically with sparse scopulae, metatarsi IV with numerous long setae ventrally.

Abdomen elongate-oval, 3.5 long; white, with yellowish white lanceolate bands (Fig. 18).

Palp.Yellow, with dark brown cymbium. Measurements: femur 1.40 , patella 0.42 , tibia 0.70 , cymbium 1.19. Palp spination: femur d0-0-2, pl0-0-1 (hair-like thin setae), patella d1-0-2, pl0-1-0, tibia with DTA and numerous (about 1.5 dozen) long setae dorsally (Fig. 15, 16), pl0-0-2 and retrolateral long hears, cymbium with a transverse row of 4 long dorsal setae. Tibia about 0.6 times of cymbium length (Fig. 15), with short RTA (about 0.35 times shorter than tibia). Oblong cymbium with long tip (about 0.4 times of cymbium length), distinctly bent dorsally (Figs 9, 15). Cymbial spur $(C S$, Fig. 9, 16) curved; its length equal to tibia length. Tegulum slightly oval, about 1.2 longer than wide; embolic base in apical position (Fig. 9); conductor membranous; TA long, thin hook-shaped (Fig. 9).

Female. See [Merkens, Wunderlich, 2000: 43].

DISTRIBUTION. Europe: Germany, Hungary [WSC, 2021]. Ukraine: Donetsk Area [Ponomarev et al., 2016]. Kazakhstan: West Kazakhstan Area [Tsvetkov et al., 2006], Mangistau (=Mangyshlak) Area [Ponomarev, Abdurakhmanov, 2014]. Russia: Kalmykia [Tsvetkov et al., 2006], Volgograd Area [Ponomarev, Khnykin, 2013], Stavropol Territory [Ponomarev et al., 2017], Daghestan [Ponomarev et al., 2019].

Acknowledgments. We are grateful to Gyulli Sh. Farzalieva (Perm State University, Perm) for her help with producing digital images. Special thanks go to D.V. Logunov (Manchester, UK) for editing the English of the final draft.

\section{References}

Bayer S. 2014. Miscellaneous notes on European and African Cheiracanthium species (Araneae: Miturgidae) // Arachnologische Mitteilungen. Bd.47. P.19-34.

Benoit P.L.G. 1977. Fam. Clubionidae // La faune terrestre de l'île de Sainte-Hélène IV. Annales, Musée Royal de l'Afrique Centrale, Sciences zoologiques. No.220. P.64-81.

Chen S.H., Huang W.J., Chen S.C., Wang Y. 2006. Two new species and one newly recorded species of the genus Cheiracanthium (Araneae: Miturgidae) from Taiwan // BioFormosa. Vol.41. P.9-18.

Chyzer C., Kulczyński W. 1897. Araneae Hungariae. Budapest: Academia Scientarum Hungaricae. T.2. P.147-366.

Deeleman-Reinhold C.L. 2001. Forest spiders of South East Asia: with a revision of the sac and ground spiders (Araneae: Clu- bionidae, Corinnidae, Liocranidae, Gnaphosidae, Prodidomidae and Trochanterriidae). Leiden: Brill. 591 p.

Esyunin S.L., Zamani A. 2020. 'Conundrum of esoterica': on the long-forgotten genus Eutittha Thorell, 1878, with new taxonomic considerations in Cheiracanthium C. L. Koch, 1839 (Araneae: Cheiracanthiidae) // Journal of Natural History. Vol.54. No.19/20. P.1293-1323.

Lotz L.N. 2007. The genus Cheiracanthium (Araneae: Miturgidae) in the Afrotropical region. 1. Revision of known species // Navorsinge van die Nasionale Museum Bloemfontein. Vol.23. P.1-76.

Marusik Yu.M., Fomichev A.A. 2016. A new species of Cheiracanthium (Araneae: Cheiracanthiidae) from Mongolia // Indian Journal of Arachnology. Vol.5. No.1/2. P.79-83.

Marusik Yu.M., Kovblyuk M.M. 2011. [Spiders (Arachnida, Aranei) of Siberia and Russian Far East]. Moscow: KMK Scientific Press. 344 p. [In Russian]

Merkens S., Wunderlich J. 2000. Zwei für Deutschland neue Spinnenarten (Araneae): Enoplognatha serratosignata (L. Koch) (Theridiidae) und Cheiracanthium gratum Kulczynski (Clubionidae) // Arachnologische Mitteilungen. Bd.19. S.41-48.

Morano E., Bonal R. 2016. Cheiracanthium ilicis sp. n. (Araneae, Eutichuridae), a novel spider species associated with Holm Oaks (Quercus ilex) // ZooKeys. Vol.601. P.21-39.

Paik K.Y. 1990. Korean spiders of the genus Cheiracanthium (Araneae: Clubionidae) // Korean Arachnology. Vol.6. No.1. P.1-30.

Ponomarev A.V., Abdurakhmanov G.M. 2014. [Spiders (Aranei) of northern Caspian Sea coast and islands] // Yugh Rossii: ekologiya, razvitie. No.1. P.76-121 [in Russian].

Ponomarev A.V., Alekseev S.K., Kozminykh V.O., Shmatko V.Yu. 2017. Spiders (Arachnida: Aranei) of Stavropol Province, Russia // Arthropoda Selecta. Vol.26, No.2. P.155-173.

Ponomarev A.V., Aliev M.A., Khabiev G.N., Shmatko V.Yu. 2019. New data on the spider fauna (Aranei) of Dagestan, Russia // Arthropoda Selecta. Vol.28. No.2. P.309-334.

Ponomarev A.V., Khnykin A.S. 2013. [Spiders (Aranei) of Volgograd City and its adjacensis] // Yugh Rossii: ekologiya, razvitie. No.4. P.109-136 [in Russian].

Ponomarev A.V., Prokopenko E.V., Ivliev P.P., Shmatko V.Y. 2016. [Spiders (Aranei) of the coast of Taganrog Bay (the Sea of Azov) and the Don River delta] // Caucasian Entomological Bulletin. Vol.12. No.1. P.3-28 [in Russian].

Tsvetkov A.S., Ponomarev A.V., Khanov T.V. 2006. [An addition to the fauna of spiders (Aranei) of the Northern Caspian basin] // Caucasian Entomological Bulletin. Vol.2. No.2. P.165-166 [in Russian].

WSC 2021. World Spider Catalog. Natural History Museum Bern, online at: http://wsc.nmbe.ch, version 22.0 (accessed on March $3,2021)$.

Wunderlich J. 2012. Few rare and a new species of spiders (Araneae) from Portugal, with resurrection of the genus Chiracanthops Mello-Leitão 1942 (Clubionidae: Eutichurinae) // Beiträge zur Araneologie. Bd.8. P.183-191.

Zhang J.S., Zhang G.R., Yu H. 2018. Four species of spider genus Cheiracanthium C. L. Koch, 1839 (Araneae, Eutichuridae) from Jinggang Mountains, Jiangxi Province, China // ZooKeys. Vol.762. P.33-45.

Responsible editor D.V. Logunov 